\title{
Theories and Determinants of Voluntary Disclosure
}

\author{
Nermeen F. Shehata ${ }^{1}$ \\ ${ }^{1}$ Faculty of Commerce, Cairo University, Giza, Egypt \\ Correspondence: Nermeen F. Shehata, Faculty of Commerce, Cairo University, Giza, Egypt. E-mail: \\ nfshehata@gmail.com
}

Received: December 16, 2013

Accepted: December 29, 2013

Online Published: January 6, 2014

doi:10.5430/afr.v3n1p18

URL: http://dx.doi.org/10.5430/afr.v3n1p18

\begin{abstract}
This paper aims to discuss the theoretical aspects of voluntary disclosure in terms of its role in the economy, the theories that are usually used through the literature to explain voluntary disclosure, its determinants, and the common sources of voluntary information disclosure. Theories related to voluntary disclosure that are commonly used through the literature include agency theory, signalling theory, capital need theory, and legitimacy theory. Determinants of voluntary disclosure fall into motivations and constraints. Finally, different sources of voluntary information disclosure are addressed clarifying why the annual reports are the most preferred source of information. The paper provides a snapshot to different parties interested in voluntary disclosure including academics and practitioners. Academics would use this paper while designing empirical voluntary disclosure research. Practitioners could probably better understand companies' behaviours towards increased or decreased voluntary information disclosure.
\end{abstract}

Keywords: Voluntary, Disclosure, Agency theory, Capital need theory, Signalling theory, Legitimacy theory

\section{Introduction}

Transparency and disclosure represent one of the pillars of corporate governance. Several scandals have occurred worldwide due to lack or improper corporate disclosures. Different stakeholders use corporate disclosure in their decision-making process. Disclosure is defined in the accounting literature as "informing the public by financial statements of the firm" (Ağca \& Önder, 2007: 241). Disclosure is also defined as "the communication of economic information, whether financial or nonfinancial, quantitative or otherwise concerning a company's financial position and performance" (Owusu-Ansah, 1998: 608).

Corporate disclosure falls into two broad categories: mandatory and voluntary. On one hand, mandatory disclosure consists of information disclosed in order to comply with the requirements of laws and regulations. On the other hand, voluntary disclosure is any information disclosed in addition to the mandatory disclosure. Voluntary disclosure is defined by Meek et al. (1995: 555) as "free choices on the part of company managements to provide accounting and other information deemed relevant to the decision needs of users of their annual reports." Moreover, voluntary disclosure may include disclosure "recommended by an authoritative code or body" (Hassan \& Marston, 2010: 7).

Much of the literature on voluntary disclosure in accounting considers the economic based models of disclosure by seeking to link financial reporting to economic consequences (Verrecchia, 2001). Investors - shareholders and debt-holders - are basically savers who want to invest their money in a 'good' business. However, linking savings to business investment opportunities is a complex process due to information asymmetry, where entrepreneurs have more and better information about businesses than savers. This leads to the agency problem: when savers invest in a business, they delegate their decision-making authority to entrepreneurs; in other words, savers are not actively involved in a business's management (Healy \& Palepu, 2001).

Mitigating the agency problem can be attempted through optimal contracting in areas such as compensation agreements, which help in bringing entrepreneur's interests in line with investor's interests (Healy \& Palepu, 2001). The presence of the board of directors in a company, who should be acting, not only independently from management, but also to monitor the company's managers, is a potential solutions to the agency problem (Healy \& Palepu, 2001). Another solution is the presence of information intermediaries such as financial analysts that are involved in revealing any exploitation of a firm's resources by managers (Healy \& Palepu, 2001).

Corporate reporting regulations aim at providing investors with the minimum amount of information that can facilitate effective investment decisions making (Griffin \& Williams, 1960; Wolk et al., 1992). Information is 
communicated to investors whether directly, via financial reports and press releases, or indirectly, via information intermediaries such as financial analysts or financial intermediaries such as banks (Healy \& Palepu, 2001) as shown in Figure 1.

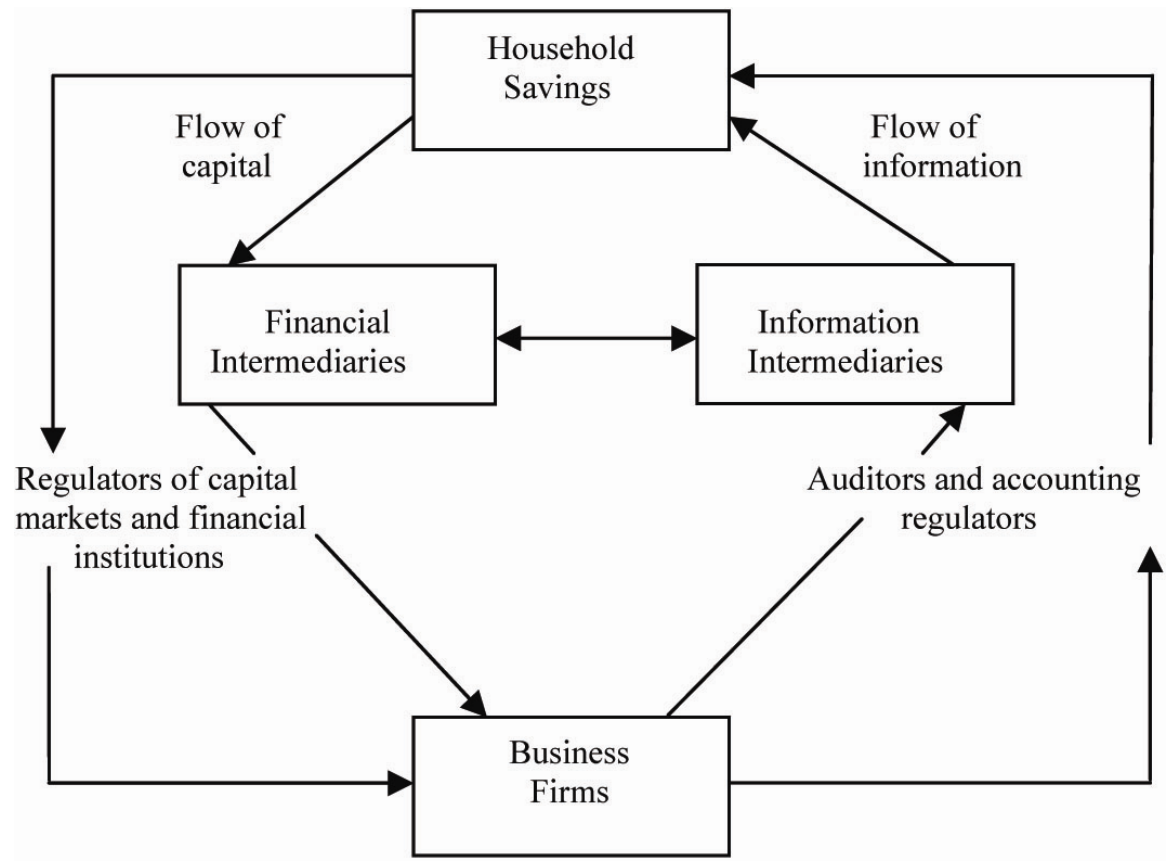

Figure 1. Financial and information flows in a capital market economy

Source: Healy \& Palepu (2001: 408)

It has been argued that managers should voluntarily disclose information that would satisfy the needs of various stakeholders (Meek et al., 1995). Voluntary disclosure is aimed at providing a clear view to stakeholders about the business's long-term sustainability and reducing information asymmetry and agency conflicts between managers and investors (Healy \& Palepu, 2001; Boesso \& Kumar, 2007). However, Core (2001) and Einhorn and Ziv (2012) argued that voluntary disclosure will still remain a matter of biased information selected by managers.

The purpose of this manuscript is to discuss the theoretical background of voluntary disclosure in terms of the theories that are usually used through the literature to explain voluntary disclosure, its determinants, and the common sources of voluntary information disclosure. Accordingly, the paper is divided into the following sections: Section 2 presents the theories related to voluntary disclosure, including agency theory, signalling theory, capital need theory, and legitimacy theory; Section 3 provides a detailed discussion of the determinants of voluntary disclosure in terms of its motivations and constraints; Section 4 discusses the different sources of voluntary disclosures; and finally, Section 5 provides a summary to the paper.

\section{Theories explaining voluntary disclosures practices}

Several theories have been found through the literature to explain voluntary disclosure practices, including agency theory, signalling theory, capital need theory, and legitimacy theory.

\subsection{Agency theory}

Jensen \& Meckling (1976: 308) define the agency relationship as "a contract under which one or more persons (the principals) engage another person (the agent) to perform some service on their behalf which involves delegating some decision-making authority to the agent." Agents correspond to managers, whereas principals correspond to shareholders from a companies' perspective. Agency costs stem from the assumption that the two parties, agents and principals, have different interests. Monitoring costs are paid by the principals, shareholders, to limit the agents' aberrant activities. Bonding costs are paid by the agents, managers, to guarantee that no harm of the principal's interests will result from their decisions and actions. Residual loss stems when decisions of the agents diverge from decisions that would maximise the principal's welfare. Accordingly, the agency cost is the summation of the monitoring cost, bonding cost, and the residual loss (Jensen \& Meckling, 1976). 
The agency relationship leads to the information asymmetry problem due to the fact that managers can access information more than shareholders (Jensen \& Meckling, 1976). Optimal contracts is one of the means of mitigating the agency problem as it helps in bringing shareholders' interests in line with managers' interests (Healy \& Palepu, 2001). In addition, voluntary disclosure is another means of mitigating the agency problem, where managers disclose more voluntary information reducing the agency costs (Barako et al., 2006) and also to convince the external users that managers are acting in an optimal way (Watson et al., 2002).

Finally, regulations are another means of mitigating the agency problem as they require managers to fully disclose private information (Healy \& Palepu, 2001). However, full disclosure is never guaranteed even in the presence of regulations (Al-Razeen \& Karbhari, 2004). The absence of full disclosure is explained by the conflict that exists between the interests of managers and shareholders (Lev \& Penman, 1990; Samuels, 1990). In addition, corporate reporting regulations are intended to provide investors with the minimum quantity of information that helps in the decision-making process (Al-Razeen \& Karbhari 2004).

\subsection{Signalling theory}

Although the signalling theory was originally developed to clarify the information asymmetry in the labour market (Spence, 1973), it has been used to explain voluntary disclosure in corporate reporting (Ross, 1977). As a result of the information asymmetry problem, companies signal certain information to investors to show that they are better than other companies in the market for the purpose of attracting investments and enhancing a favourable reputation (Verrecchia, 1983). Voluntary disclosure is one of the signalling means, where companies would disclose more information than the mandatory ones required by laws and regulations in order to signal that they are better (Campbell et al., 2001).

\subsection{Capital need theory}

Companies aim to attract external finance to increase their capital, either by debt or equity. The capital need theory suggests that voluntary disclosure helps in achieving a company's need to raise capital at a low cost (Choi, 1973). In 2001, according to the Improved Business Reporting: Insights into Enhancing Voluntary Disclosure, which is published by the Financial Accounting Standards Board as part of their broader Business Reporting Research Project, the competition for capital leads to increased voluntary disclosure. The rationale beyond this is the fact that "a company's cost of capital is believed to include a premium for investors' uncertainty about the adequacy and accuracy of the information available about the company." Therefore, reduction in a company's cost of capital is achieved when investors are able to interpret the company's economic prospects through voluntary disclosure (Financial Accounting Standards Board, 2001). The relationship between voluntary disclosure and cost of capital was thought to be a positive relationship; the higher the information disclosures, the lower the cost of capital. However, as Botosan (2006: 3) highlighted that another "stream of research indicates that certain types of disclosure might have the opposite effect."

\subsection{Legitimacy theory}

The legitimacy theory assumes that a company has no right to exist unless its values are being perceived as matching with that of the society at large where it operates (Dowling \& Pfeffer, 1975; Lindblom, 1994; Magness, 2006). Accordingly, the idea of the legitimacy theory resembles a social contract between the company and the society (Magness, 2006). Since the objective of accounting is providing users with information that help in decision-making, i.e., satisfy social interests, the theory has been integrated in accounting studies as a "means of explaining what, why, when and how certain items are addressed by corporate management in their communication with outside audiences" (Magness, 2006: 542).

Since the legitimacy theory is based on the society's perception, management is forced to disclose information that would change the external users' opinion about their company (Cormier \& Gordon, 2001). The annual report has been detected as an important source of legitimation (Dyball, 1998; O'Donovan, 2002). Legitimisation can occur both through mandatory disclosures - disclosures provided in financial statements because of regulations, and voluntary disclosures provided in other sections of the annual report (Magness, 2006; Lightstone \& Driscoll, 2008).

\section{Determinants of voluntary disclosure}

Through the literature, factors affecting the provision of and need for voluntary disclosure have been assembled by Healy \& Palepu (2001) and Graham et al. (2005). The previous studies categorise the factors affecting managers' decisions to voluntarily disclose information among motivations and constraints. Motivations to voluntary disclosure include capital markets transactions/ information asymmetry, corporate control contest, stock compensation, increased analyst coverage, management talent signalling, and limitations of mandatory disclosure. Constraints on 
voluntary disclosure comprise: disclosure precedent, proprietary costs, agency costs, and political costs. Litigation cost can be viewed as a motive or constraint.

\subsection{Motivations to voluntary disclosure}

The six motivations to voluntary disclosure according to Healy and Palepu (2001) and Graham et al. (2005) are as follows:

\subsubsection{Capital markets transactions/ information asymmetry}

When a company's managers want to issue new capital through equity or debt, the perception of investors towards information asymmetry between managers and those outside investors needs to be reduced (Myers \& Majluf, 1984). As a consequence, the cost of external financing and capital should be decreased. Voluntary information disclosure can help achieve this objective, where a reduction in information asymmetry may occur when voluntary disclosure is increased to outside investors (Diamond \& Verrecchia, 1991; Kim \& Verrecchia, 1994; Healy \& Palepu, 2001; Graham et al., 2005).

\subsubsection{Corporate control contest}

The possibility of a firm's undervaluation is another motive for managers to increase voluntary disclosure in order to reduce such a possibility, especially when poor earnings and stock performance might lead to the risk of job loss (Healy \& Palepu, 2001; Graham et al., 2005), for example, the case of poor stock performance associated with chief executive officers turnovers (Warner et al., 1988; Weisbach, 1988). As a result, managers increase information disclosure as in order to retain corporate control, to explain the reasons for poor performance and reduce the possibility of undervaluing the company's stocks (Healy \& Palepu, 2001).

\subsubsection{Stock compensation}

Rewarding managers with stock-based compensation plans, such as stock appreciation rights and stock option grants, is another motive for increased voluntary information disclosure (Healy \& Palepu, 2001; Graham et al., 2005). Two reasons justify this motivation: first, managers will have incentives to reduce contracting costs associated with stock compensation for new employees when they act in the interest of existing shareholders (Aboody \& Kasznik, 2000). Second, when managers are interested in trading their shares, they will be motivated to disclose private information to meet the insider trading rules' restrictions and to correct any undervaluation perceptions before the stock option awards expire (Healy \& Palepu, 2001; Graham et al., 2005).

\subsubsection{Increased analyst coverage}

Increased voluntary disclosure of information decreases the cost of information acquisition by analysts; since management's private information is not totally required by mandatory disclosure. The number of analysts following the company would increase as a result of increasing the amount of information available to them (Bhushan, 1989a, b; Lang \& Lundholm, 1996; Graham et al., 2005).

\subsubsection{Management talent signalling}

Investors' perception of managers' ability to predict future changes in the company's economic environment and respond to them is one of the determinants of a company's market value. Accordingly, talented managers voluntarily disclose information about earnings forecasts to reveal their talent (Trueman, 1986; Healy \& Palepu, 2001; Graham et al., 2005). Graham et al. (2005) argue that managers limit information disclosures that may be used against them by regulators.

\subsubsection{Limitations of mandatory disclosure}

Since regulations and laws do not usually meet the need of information by investors through mandatory disclosure (Graham et al., 2005), because in most cases laws and regulations provide investors with the minimum quantity of information that helps in the decision-making process (Al-Razeen \& Karbhari, 2004), the need for voluntary information disclosure arises. Accordingly, voluntary disclosure is perceived as filling the gaps missed by mandatory disclosure (Graham et al., 2005).

\subsection{Constraints on voluntary disclosure}

Factors that limit and/or prevent managers from voluntarily disclosing corporate information are identified by Graham et al. (2005): 


\subsubsection{Disclosure precedent}

Setting a disclosure precedent is one of the factors that reduce voluntary information disclosure, as it means that managers have to maintain the same pattern in the future, although this may be difficult to preserve (Graham et al., 2005). Moreover, the market would expect the company to be committed to the new disclosures and maintain them even if the news is good or bad. This provides an incentive for managers to reduce voluntary disclosures (Graham et al., 2005).

\subsubsection{Proprietary costs}

Proprietary information has been defined by Dye (1985: 123) as "any information whose disclosure potentially alters a firm's future earnings gross of senior management's compensation" including information that may decrease customer's demand for a company's products. Accordingly, managers favour not to disclose information that may affect the competitive position of their company in a market, even if this would increase the associated cost of capital. It can be said that proprietary costs represent the competitive disadvantage (Campbell et al., 2001). Managers can be expected to disclose aggregate performance information when their company has different performance across its segments (Hayes \& Lundholm, 1996; Healy \& Palepu, 2001). On the other hand, firms with similar declining profitability across its segments will disclose more segment information (Piotroski, 1999).

\subsubsection{Agency costs}

Nanda et al. (2003) and Berger and Hann (2003) argue that agency issues are one of the reasons beyond reduced voluntary disclosure. Managers' desire to keep away from potential attention and follow up from stockholders and bondholders about unimportant items, such as career concerns and external reputation, is one of the factors that limit voluntary disclosure (Graham et al., 2005).

\subsubsection{Political costs}

Generally speaking, managers prefer not to disclose voluntary information that regulators might use against them (Graham et al., 2005). According to Watts \& Zimmerman (1978), political costs depend on the firm's size. Large companies with high profits are more likely to decrease voluntary information disclosure level, to avoid being subject to any political attacks such as the threat of nationalisation and to reduce the expected attention that would be drawn based on high reported profits (Wallace et al., 1994; Camfferman \& Cooke, 2002; Alsaeed, 2006). Income taxes are also among the political costs incurred, which depend heavily on the reported profits; the higher the reported profits, the more taxes on business profits (political costs) being paid by a firm.

\subsection{Litigation costs}

Litigation can be considered as a motivation to increase disclosure or a constraint against disclosure. On one hand, managers are encouraged to increase voluntary disclosure not to be subjected to legal actions against them resulting from untimely or inadequate disclosures. In addition, managers will give due care to disclosing more information, especially bad news to limit the threat of litigation (Skinner, 1994, 1997; Francis et al., 1994). On the other hand, managers may reduce voluntary disclosures of forward looking information as a result of litigation, especially if managers face the risk of being penalised against their forecasts (Healy \& Palepu, 2001; Graham et al., 2005).

\section{Sources of voluntary disclosures}

Corporate information can be represented across a variety of voluntary communication sources including magazines, newspapers, press reports, stockbrokers' advice, letters to shareholders, management forecasts, analysts' presentations, employee reports, interim reports, and annual reports (Healy \& Palepu, 2001). However, to many users in developed and developing countries, the annual report is perceived as the most important, frequent and major source of information among all other sources (Epstein \& Pava, 1993; Lang \& Lundholm, 1993; Cook \& Sutton, 1995; Gray et al., 1996; Abu-Nassar \& Rutherford, 1996; Bartlett \& Chandler, 1997; Botosan, 1997; Naser et al., 2003; Akhtaruddin, 2005; Alattar \& Al-Khater, 2007; Catasús, 2008; Chau \& Gray, 2010).

Moreover, the annual reports provide a core public disclosure source of information, even though other reports and company websites may provide additional information (Patel \& Dallas, 2002). The annual reports are considered the only formal source of information in many developing countries (Naser \& Nuseibeh, 2003; Al-Razeen \& Karbhari, 2007), although shareholders might have access and get information directly through contacting companies' management (Naser \& Nuseibeh, 2003). The annual reports are also produced regularly and are available for public scrutiny (Catasús, 2008). 
Finally, Lang and Lundholm (1993) argued that annual report disclosure is positively associated with disclosure level provided by other media. Accordingly, even though there are means of corporate reporting other than the annual report, they still serve as a good proxy for disclosure level provided by companies (Lang \& Lundholm, 1993).

The annual report aims to convey useful information to interested parties in the company, especially the shareholders (Zairi \& Letza, 1994). Information included in the annual report can be divided into two parts: the first part represents the financial information, including the financial statements, auditor's report and notes to the financial statements, whereas the second part is concerned with the non-financial information, including all other reports such as the chairman's report, the directors' reports, the management discussion and analysis section (Naser \& Nuseibeh, 2003). Although management discussion and analysis section is among the non-financial information category, it has been identified as a source of useful information that may be used for financial analysis (Clarkson et al., 1999; Barron et al., 1999).

Finally, it should be noted that opponents to annual reports argue that they do not provide a rational vision about a company's future; they are used more for advertising and public relations purposes rather than being used for decision-making (Jacobson, 1988).

\section{Summary and conclusion}

This paper provided a snapshot of the theoretical aspect of voluntary disclosure. Theories related to voluntary disclosure that are commonly used through the literature include agency theory, signalling theory, capital need theory, and legitimacy theory. Determinants of voluntary disclosure fall into motivations and constraints. Six motivations were discussed: capital markets transactions/ information asymmetry, corporate control contest, stock compensation, increased analyst coverage, management talent signalling, and limitations of mandatory disclosure. Constraints included: disclosure precedent, proprietary costs, agency costs, and political costs. Finally, different sources of voluntary information disclosure were addressed clarifying why the annual reports are the most preferred source of information. Future research is still needed by academics since no consensus is found regarding certain aspects of voluntary disclosure such as its relationship with the cost of capital. Practitioners should take into account the biases of the disclosed information which cannot be eliminated concerning voluntary disclosure.

\section{References}

Aboody, D., \& Kasznik, R. (2000). CEO stock options awards and the timing of corporate voluntary disclosures, Journal of Accounting and Economics, 29(1), pp. 73-100. http://dx.doi.org/10.1016/S0165-4101(00)00014-8

Abu-Nassar, M., \& Rutherford, B.A. (1996). External users of financial reports in less developed countries: the case of Jordan, British Accounting Review, 28(1), pp. 73-87. http://dx.doi.org/10.1006/bare.1996.0004

Ağca, A., \& Önder, S. (2007). Voluntary disclosure in Turkey: a study on firms listed in Istanbul stock exchange (ISE), Problems and Perspectives in Management, 5(3), pp. 241-286.

Akhtaruddin, M. (2005). Corporate mandatory disclosure practices in Bangladesh, The International Journal of Accounting, 40(4), pp. 399-422. http://dx.doi.org/10.1016/j.intacc.2005.09.007

Alattar, J.M., \& Al-Khater, K. (2007). An empirical investigation of users' views on corporate annual reports in Qatar, International Journal of Commerce and Management, 17(4), pp. 312-325. http://dx.doi.org/10.1108/10569210710844381

Al-Razeen, A., \& Karbhari, Y. (2004). Interaction between compulsory and voluntary disclosure in Saudi Arabian corporate annual reports, Managerial Auditing Journal, 19(3), pp. 351-360. http://dx.doi.org/10.1108/02686900410524364

Alsaeed, K. (2006). The association between firm-specific characteristics and disclosure: the case of Saudi Arabia, Managerial Auditing Journal, 21(5), pp. 476-496. http://dx.doi.org/10.1108/02686900610667256

Barako, D.G., Hancock, P., \& Izan, H.Y. (2006). Factors influencing voluntary corporate disclosures by Kenyan companies, Corporate Governance: An International Review, 14(2), pp. 107-125. http://dx.doi.org/10.1111/j.1467-8683.2006.00491.x

Barron, O.C., Kile C., \& O'Keefe, T. (1999). MD\&A quality as measured by the SEC and analysts' earnings forecasts, Contemporary Accounting Research, 16(1), pp. 75-109. http://dx.doi.org/10.1111/j.1911-3846.1999.tb00575.x

Bartlett, S.A., \& Chandler, R.A. (1997). The corporate report and private shareholder: Lee and Tweedie twenty years on, British Accounting Review, 29(3), pp. 245-261. http://dx.doi.org/10.1006/bare.1996.0044 
Berger, P., \& Hann, R. (2003). Segment disclosures, proprietary costs, and the market for corporate control, Working Paper, University of Chicago and University of Southern California.

Bhushan, R. (1989a). Collection of information about publicly traded firms: theory and evidence, Journal of Accounting and Economics, 11(2/3), pp. 183-207. http://dx.doi.org/10.1016/0165-4101(89)90005-0

Bhushan, R. (1989b). Firm characteristics and analyst following, Journal of Accounting and Economics, 11(2/3), pp. 255-275. http://dx.doi.org/10.1016/0165-4101(89)90008-6

Boesso, G., \& Kumar, K. (2007). Drivers of corporate voluntary disclosure- a framework and empirical evidence from Italy and the United States, Accounting, Auditing and Accountability Journal, 20(2), pp. 269-296. http://dx.doi.org/10.1108/09513570710741028

Botosan, C.A. (1997). Disclosure level and the cost of equity capital, Accounting Review, 72, pp. 323-350.

Botosan, C.A. (2006). Disclosure and the cost of capital: What do we know? Accounting and Business Research, International Accounting Policy Forum, pp. 31-40. http://dx.doi.org/10.1080/00014788.2006.9730042

Camfferman, K., \& Cooke, T.E. (2002). An analysis of disclosure in the annual reports of UK and Dutch companies, Journal of International Accounting Research, 1, pp. 3-30. http://dx.doi.org/10.2308/jiar.2002.1.1.3

Campbell, D., Shrives, P., \& Saager, H.B. (2001). Voluntary disclosure of mission statements in corporate annual reports: signaling what and to whom?, Business and Society Review, 106(1), pp. 65-87. http://dx.doi.org/10.1111/0045-3609.00102

Catasús, B. (2008). In search of accounting absence, Critical Perspectives on Accounting, 19(7), pp. 1004-1009. http://dx.doi.org/10.1016/j.cpa.2007.02.002

Chau, G., \& Gray, S.J. (2010). Family ownership, board independence and voluntary disclosure: evidence from Hong Kong, Journal of International Accounting, Auditing and Taxation, 19(2), pp. 93-109. http://dx.doi.org/10.1016/j.intaccaudtax.2010.07.002

Choi, F.D.S. (1973). Financial disclosure and entry to the European capital market, Journal of Accounting Research, 11(2), pp. 159-175. http://dx.doi.org/10.2307/2490187

Clarkson, P.M., Kao, J.L., \& Richardson, G.D. (1999). Evidence that management discussion and analysis (MD\&A) is a part of a firm's overall disclosure package, Contemporary Accounting Research, 16(1), pp. 111-134. http://dx.doi.org/10.1111/j.1911-3846.1999.tb00576.x

Cook, M., \& Sutton, M.H. (1995). Summary annual reporting: a cure for information overload, Financial Executive, 11(1), pp. 12-15.

Core, J.E. (2001). A review of the empirical disclosure literature: Discussion, Journal of Accounting and Economics, 31(1/3), pp. 441-456. http://dx.doi.org/10.1016/S0165-4101(01)00036-2

Cormier, D., \& Gordon, I. (2001). An examination of social and environmental reporting strategies, Accounting, Auditing and Accountability Journal, 14(5), pp. 587-616. http://dx.doi.org/10.1108/EUM0000000006264

Diamond, D., \& Verrecchia, R. (1991). Disclosure, liquidity, and the cost of capital, The Journal of Finance, 46(4), pp. 1325-1355. http://dx.doi.org/10.2307/2328861

Dowling, J., \& Pfeffer, J. (1975). Organisational legitimacy: social values and organizational behaviour, Pacific Sociological Review, 18(1), pp. 122-36. http://dx.doi.org/10.2307/1388226

Dyball, M. (1998). Corporate annual reports as promotional tools: the case of Australian National industries Limited, Asian Review of Accounting, 6(2), pp. 25-53. http://dx.doi.org/10.1108/eb060696

Dye, R. (1985). Disclosure of nonproprietary information, Journal of Accounting Research, 23(1), pp. 123-145. http://dx.doi.org/10.2307/2490910

Einhorn, E., \& Ziv, A. (2012). Biased voluntary disclosure, Review of Accounting Studies, 17(2), pp. 420-442. http://dx.doi.org/10.1007/s11142-011-9177-0

Epstein, M.J., \& Pava, M.L. (Eds). (1993). The Shareholder's Use of Corporate Annual Report (Connecticut: JAI Press).

Financial Accounting Standards Board (2001). Improving Business Reporting: Insights into Enhancing Voluntary Disclosure, The Financial Accounting Standards Board.

Francis, J., Philbrick, D. and Schipper, K. (1994). Shareholder litigation and corporate disclosures, Journal of 
Accounting Research, 32(2), pp. 137-165. http://dx.doi.org/10.2307/2491279

Graham, J.R., Harvey, C.R., \& Rajgopal, S. (2005). The economic implications of corporate financial reporting, Journal of Accounting and Economics, 40, pp. 3-37. http://dx.doi.org/10.1016/j.jacceco.2005.01.002

Gray, R., Owen, D., \& Adams, C. (Eds) (1996). Accounting and Accountability: Changes and Challenges in Corporate Social and Environmental Reporting (London: Prentice-Hall).

Griffin, C.H., \& Williams, T.H. (1960). Measuring adequate disclosure, Journal of Accountancy, 109, pp. 43-48.

Hassan, O., \& Marston, C. (2010). Disclosure measurement in the empirical accounting literature: a review article, Economics and Finance Working Paper Series, Brunel University, Working Paper No. 10-18. http://dx.doi.org/10.2139/ssrn.1640598

Hayes, R., \& Lundholm, R. (1996). Segment reporting to the capital market in the presence of a competitor, Journal of Accounting Research, 34(2), pp. 261-280. http://dx.doi.org/10.2307/2491502

Healy, P.M., \& Palepu, K.G. (2001). Information asymmetry, corporate disclosure, and the capital markets: a review of the empirical disclosure literature, Journal of Accounting and Economics, 31(1/3), pp. 405-440. http://dx.doi.org/10.1016/S0165-4101(01)00018-0

Jacobson, G. (1988). How valuable is the annual report? Management Review, 77(10), pp. 51-53.

Jensen, M.C., \& Meckling, W.H. (1976). Theory of the firm: managerial behavior, agency costs and ownership structure, Journal of Financial Economics, 3(4), pp. 305-360. http://dx.doi.org/10.1016/0304-405X(76)90026-X

Kim, O. and Verrecchia, R. (1994). Market liquidity and volume around earnings announcements, Journal of Accounting and Economics, 17(1/2), pp. 41-68. http://dx.doi.org/10.1016/0165-4101(94)90004-3

Lang, M., \& Lundholm, R. (1993). Cross-sectional determinants of analyst ratings of corporate disclosures, Journal of Accounting Research, 31(2), pp. 246-271. http://dx.doi.org/10.2307/2491273

Lang, M., \& Lundholm, R. (1996). Corporate disclosure policy and analysts behaviour, The Accounting Review, 71, pp. 467-492.

Lev, B., \& Penman, S.H. (1990). Voluntary forecast disclosure, non disclosure and stock prices, Journal of Accounting Research, 28(1), pp. 49-76. http://dx.doi.org/10.2307/2491217

Lightstone, K., \& Driscoll, C. (2008). Disclosing elements of disclosure: a test of legitimacy theory and company ethics, Canadian Journal of Administrative Sciences, 25(1), pp. 7-21. http://dx.doi.org/10.1002/cjas.50

Lindblom, C.K. (1994). The implications of organizational legitimacy for corporate social performance and disclosure, Critical Perspectives on Accounting Conference. New York.

Magness, V. (2006). Strategic posture, financial performance and environmental disclosure: an empirical test of legitimacy theory, Accounting, Auditing and Accountability Journal, 19(4), pp. 540-563. http://dx.doi.org/10.1108/09513570610679128

Meek, G.K., Roberts, C.B., \& Gray, S.J. (1995). Factors influencing voluntary annual report disclosures by U.S., U.K. and Continental European multinational corporations, Journal of International Business Studies, 26(3), pp. 555-572. http://dx.doi.org/10.1057/palgrave.jibs.8490186

Myers, S., \& Majluf, N., (1984). Corporate financing and investment decisions when firms have information that investors do not have, Journal of Financial Economics, 13(2), pp. 187-222. http://dx.doi.org/10.1016/0304-405X(84)90023-0

Nanda, D.J., Nagar, V., \& Wysocki, P. (2003). Discretionary disclosure and stock-based incentives, Journal of Accounting and Economics, 34(1/3), pp. 283-309.

Naser, K., \& Nuseibeh, R. (2003). Users' perceptions of corporate reporting: evidence from Saudi Arabia, The British Accounting Review, 35(2), pp. 129-153. http://dx.doi.org/10.1016/S0890-8389(03)00015-5

Naser, K., Nuseibeh, R., \& Al-Hussaini, A. (2003). Users' perceptions of various aspects of Kuwaiti corporate reporting, Managerial Auditing Journal, 18(6/7), pp. 599-617. http://dx.doi.org/10.1108/02686900310482731

O'Donovan, G. (2002). Environmental disclosures in the annual report: extending the applicability and predictive power of legitimacy theory, Accounting, Auditing and Accountability Journal, 15(3), pp. 344-71. http://dx.doi.org/10.1108/09513570210435870 
Owusu-Ansah, S. (1998). The impact of corporate attributes on the extent of mandatory disclosure and reporting by listed companies in Zimbabwe, The International Journal of Accounting, 33(5), pp. 605-631. http://dx.doi.org/10.1016/S0020-7063(98)90015-2

Patel, S.A., \& Dallas, G. (2002). Transparency and disclosure: overview of methodology and study results - United States, Standard and Poor's.

Piotroski, J. (1999). Discretionary segment reporting decisions and the precision of investor beliefs, Working paper, University of Chicago.

Ross, S.A. (1977). The determination of financial structure: the incentive signaling approach, Bell Journal of Economics, 8(1), pp. 23-40. http://dx.doi.org/10.2307/3003485

Samuels, J.M. (1990). Accounting for development: an alternative approach, Research in Third World Accounting, 1, pp. $67-86$.

Skinner, D. (1994). Why firms voluntarily disclose bad news, Journal of Accounting Research, 32(1), pp. 38-61. http://dx.doi.org/10.2307/2491386

Skinner, D. (1997). Earnings disclosures and stockholder lawsuits, Journal of Accounting and Economics, 23(3), pp. 249-283. http://dx.doi.org/10.1016/S0165-4101(97)00010-4

Spence, M. (1973). Job market signalling, Quarterly Journal of Economics, 87(3), pp. 355-374 http://dx.doi.org/10.2307/1882010

Trueman, B. (1986). Why do managers voluntarily release earnings forecasts?, Journal of Accounting and Economics, 8(1), pp. 53-72. http://dx.doi.org/10.1016/0165-4101(86)90010-8

Verrecchia, R. (2001). Essays on disclosure, Journal of Accounting and Economics, 32(1/3), pp. 97-180. http://dx.doi.org/10.1016/S0165-4101(01)00025-8

Verrecchia, R.E. (1983). Discretionary disclosure, Journal of Accounting and Economics, 5(3), pp. 179-194. http://dx.doi.org/10.1016/0165-4101(83)90011-3

Wallace, R.S.O., Naser, K., \& Mora, A. (1994). The relationship between the comprehensiveness of corporate annual reports and firm characteristics in Spain, Accounting and Business Research, 25(97), pp. 41-53. http://dx.doi.org/10.1080/00014788.1994.9729927

Warner, J., Watts, R., \& Wruck, K. (1988). Stock prices and top management changes, Journal of Financial Economics, 20, pp. 461-493. http://dx.doi.org/10.1016/0304-405X(88)90054-2

Watson, A., Shrives, P., \& Marston, C. (2002). Voluntary disclosure of accounting ratios in the UK, British Accounting Review, 34(4), pp. 289-313. http://dx.doi.org/10.1006/bare.2002.0213

Watts, R.L., \& Zimmerman, J.L. (1978). Towards a positive theory of the determination of accounting standards, The Accounting Review, 53(1), pp. 112-134.

Weisbach, M. (1988). Outside directors and CEO turnover, Journal of Financial Economics, 20, pp. 431-461. http://dx.doi.org/10.1016/0304-405X(88)90053-0

Wolk, H.I., Francis, J.R., \& Tearney, M.G. (Eds) (1992). Accounting Theory: A Conceptual and Institutional Approach (Ohio: South Western Publishing).

Zairi, M., \& Letza, S. (1994). Corporate reporting, Management Decision, 32(2), pp. 30-40. http://dx.doi.org/10.1108/00251749410054792 